\title{
The First Thing We Do, Let's Pay All the Lawyers
}

\author{
Paul G. Mahoney $\dagger$
}

Ehud Kamar provides an in-depth analysis of a specific aspect of the divergence between social and private incentives to bring suit, ${ }^{1}$ a topic that has been explored more generally by Steven Shavell. ${ }^{2}$ Shareholder suits provide two social benefits: they deter wealth-destroying managerial behavior and clarify legal duties by creating precedents. Kamar argues that in order to provide plaintiffs sufficient incentive to bring suit, we may have to set damages at a level so high that risk-averse managers will become too timid to manage effectively. Conversely, if we set damages low enough to make it feasible for managers to operate in a world of legal uncertainty, we may give shareholders insufficient incentives to bring socially valuable suits. Kamar argues that when corporations purchase director and officer liability insurance, they decouple the award to the shareholder/plaintiff and the damages paid by the manager/defendant in a way that better aligns private and social incentives. Insurance acts as a private subsidy to litigation, in the sense that shareholders deliberately incur costs to encourage suits that will ultimately produce better managerial decisions.

Adhering to the commentator's traditional role as devil's advocate, I will express some skepticism that the encouragement of litigation to reduce legal uncertainty is an important function of insurance and indemnification in the corporate context. That insurance is prompted by legal uncertainty, I think, is clear. Whether insurance helps produce a more nearly optimal level of litigation is a much more complex question and, I will argue, one we lack sufficient facts to answer. As a positive account of why insurance exists, I am inclined to credit the simple view that managers want to reduce the risk of undeserved liability and shareholders want a third party to monitor management.

$\dagger$ Professor of Law and Albert C. BeVier Research Professor, University of Virginia School of Law.

2 Ehud Kamar, Shareholder Litigation Under Indeterminate Corporate Law, 66 U Chi L Rev 887 (1999).

2 See Steven Shavell, The Fundamental Divergence between the Private and the Social Motive to Use the Legal System, 26 J Legal Stud 575 (1997). 


\section{UNCERTAINTY AND INSURANCE}

Legal uncertainty is an important motivation for liability insurance. If well-meaning people cannot be sure that taking care and acting in good faith will protect against liability in all instances, there will be a demand for insurance. Even very careful drivers pay for liability insurance because there is some probability that a court will find their care inadequate. In that sense, the "puzzle" of director and officer liability insurance is no puzzle at all.

The corporate context initially appears different because the same parties (the shareholders) suffer the harm and pay for the insurance. That is, however, a function of the fact that shareholders and managers are in a contractual relationship. If $X$ and $Y$ contract with one another and $\mathrm{Y}$ can better bear a particular risk, $\mathrm{Y}$ will bear it, even if that risk happens to be the risk that $\mathrm{Y}$ will sue $X$. If managers are exposed to potential liability and the standard of care required is uncertain, they will demand greater pay to compensate for occasional judicial errors that result in liability. Because of risk aversion, the extra pay may exceed the cost of insurance.

Thus, what Kamar calls decoupling (that is, removing the link between the penalty to the wrongdoer and the recovery to the victim) is just the familiar concept of incidence-shifting often discussed in the tax literature. ${ }^{3}$ Because shareholders and managers are in privity, the party on whom a liability nominally falls will not necessarily bear the full cost. Instead, prices may adjust to shift some of that cost back to the other party. Analogous results hold in other contractual settings. In a competitive market, a product should cost more under a strict liability regime (in which manufacturers must pay compensation for accidents for which there are no cost effective precautions) than under a negligence regime. Shippers will pay less if their contract limits the carrier's liability to a fixed sum than if that liability is unlimited. ${ }^{4}$

S Economists have attempted for decades, with only limited success, to determine the actual incidence of particular taxes. See Lester C. Thurow, The Economics of Public Finance, 28 Natl Tax $J 185$ (1975). An early and influential model was provided in Arnold C. Harberger, The Incidence of the Corporation Income Tax, $70 \mathrm{~J}$ Pol Econ 215 (1962).

- For a full discussion, see Jason Scott Johnston, Strategic Bargaining and the Economic Theory of Contract Default Rules, 100 Yale L J 615, 627-31 (1990). These examples share a feature that is present in some (for example, securities fraud) but not all shareholder litigation-the distribution of the harm is not known ex ante, and therefore the liability system provides for sharing of risk among potential victims. That does not alter the fact that consumers, rather than shareholders, might bear the cost of anticipated judicial error in the form of higher product prices. 
In the standard tort law analysis, liability induces a potential injurer to take care and a potential injured to take fewer precautions against the harm. If drivers did not have to pay when they negligently injured pedestrians, people would respond by crossing the street more carefully or by walking less. Tort law's decision to pin the loss on the driver stems from a decision that the marginal investment in care by the driver is more cost effective than the marginal investment in precaution by the pedestrian. In a contractual setting, however, price adjustment is a substitute for precaution by the potential victim. Investors who might be harmed by managerial misbehavior can simply pay less for their shares. Thus, as the Jensen and Meckling model of agency costs shows, even without a liability rule, an entrepreneur selling shares to the public will internalize the cost of the harm he may cause shareholders in the future in his role as salaried manager. ${ }^{5}$

Managers therefore may view liability rules as a bonding device that enables them to credibly commit to taking adequate care, thereby increasing the value of their services. Liability changes the shareholders' estimate of the expected losses from managerial misbehavior in two ways. First, by imposing a penalty on managers, liability will reduce the probability of misbehavior. The amount of the reduction depends on the benefits that managers obtain through misbehavior, but we can assume that these benefits are less than the losses imposed on shareholdersotherwise managers and shareholders would bargain to permit the "misbehavior." Some penalty sufficient to reduce the likelihood of gain to managers will reduce the likelihood of misbehavior, whether or not that penalty sufficiently compensates shareholders. Liability can reduce the magnitude of loss as well as the probability of loss if the penalty is paid to shareholders in the form of damages.

Both the deterrence and compensation analyses, however, are incomplete until we consider the contractual nature of the relationship and determine the actual incidence of the liability payment. Because judges may make mistakes, managers will insist on insurance or indemnification, which results in sharehold-

s See Michael C. Jensen and William H. Meckling, Theory of the firm: Managerial behavior, agency costs and ownership structure, $3 \mathrm{~J}$ Fin Econ 305 (1976). I am thinking of the manager as an entrepreneur who at time $A$ owns 100 percent of the firm, at time $B$ sells 100 percent to investors, staying on as a salaried manager, and at time $\mathbf{C}$ decides whether to engage in a breach of fiduciary duty. This has the benefit of making the internalization of the breach/no breach decision clear. 
ers compensating themselves. ${ }^{6}$ Even when managers do not directly pay the damages, however, liability may still discipline managers by triggering other deterrent forces such as reputational loss, lower earnings, and a heightened risk of being fired. The insurer may also impose some external monitoring of managers that partially offsets the loss of direct financial penalties.

Note that these indirect sanctions, such as loss of reputation and future earnings, will not always come into play when the manager is found liable for breach of fiduciary duty. The insurance company, the manager's peers, and other potential employers may recognize that the manager's behavior was appropriate and the imposition of liability was the result of judicial error. By the same token, these other sanctions will sometimes be imposed even though the manager was not sued or was not found liable. The litigation system, in other words, serves as one of several constraints on managerial misbehavior, but not necessarily the most important one.

The general lesson is that decoupling of the penalty actually borne by a wrongdoer and the net compensation actually received by the victim is a natural consequence of a setting in which prices reflect expected liability, expected harm, relative costs of care, and legal uncertainty. Kamar takes this a step farther by trying to endogenize the last of these variables. He argues that decoupling is not merely a sensible response to legal uncertainty, but that decoupling, by providing an incentive for lawyers to bring suits nominally on behalf of shareholders, can reduce legal uncertainty.

The persuasiveness of the theory turns in part on one's view of the sources of legal uncertainty, or "indeterminacy," as Kamar calls it. Consider the following two stylized descriptions of corporate law. In Model A, the socially optimal behavior in any situation is discoverable by a judge ex post. Corporate statutes do not attempt to specify the optimal behavior for all situations ex ante, but instead rely on judges' application of broad principles. Accordingly, the parties are left to guess the judge's decision (which is the same as guessing the optimal behavior) and they will make their estimates with some error. The parties' inability to determine what is optimal until advised by the court is the source of indeterminacy.

- I am assuming here that all shareholders are harmed, and all are compensated, equally. If not, compensation may be a form of risk-sharing among shareholders. See note 4. 
In Model B, the parties themselves can determine the optimal behavior, but they have self-interested reasons to deviate from it. One party may accuse the other of deviation, but the accusation may itself be opportunistic. The judge must decide whether the defendant deviated from optimal behavior, and that decision is made with some error. Here, adjudication does not provide new information about what is optimal, but new information about how much the judge knows about what is optimal. Indeterminacy in this setting means that the parties are unsure what they can get away with.

Neither model, surely, is a fully accurate description of the real world. But the desirability of subsidizing litigation seems to hinge on which model comes closer to reality. In Model A, the judge knows a lot about optimal behavior that the parties are unable to determine on their own. It might make sense in that situation to subsidize litigation that will provide signals to guide future behavior. In Model B, by contrast, the parties are generally well-informed about what behavior is optimal and require only appropriate incentives. This is a problem the parties can attack contractually. They need litigation as a backstop to assure that the rules, once laid down, are followed, but not for advice on what the rules should be. They also require insurance, not as a means of inducing lawsuits that provide valuable signals about optimal behavior, but to protect managers from the consequences of judicial error.

It seems implausible that a generalist judge, far removed from the situation, will generally be better at determining optimal behavior than the parties, who are on the spot and often have specialized skills. ${ }^{7}$ Having said that, however, I will assume for the sake of argument that Model A is more accurate-defendants are uncertain what behavior is optimal, not merely about whether they will face liability given optimal behavior or whether they can escape liability given nonoptimal behavior. Considerably more than that assumption, however, is required to make a convincing case that insurance confers an important positive externality by generating socially valuable litigation.

\footnotetext{
7 The general reluctance of judges to provide advisory opinions is a small piece of evidence that judges perceive Model B as closer to reality. Were judges generally better positioned than potential litigants to determine optimal behavior, ex ante judicial consultation would be efficiency-enhancing and its failure to evolve as a common practice would be puzzling.
} 


\section{UNCERTAINTY AND SUBSIDY}

Kamar argues that given managers' inability to determine optimal behavior and the courts' ability to provide guidance, it makes sense to have frequent, small judicial "corrections" of managerial behavior. Thanks to insurance and indemnification, shareholder suits serve this corrective function. The suits impose only a modest cost on defendants and result in a net loss to shareholders, but they provide plaintiffs' lawyers an incentive to bring suits.

\section{A. Type I and Type II Plaintiff Error}

Kamar's analysis focuses on defendants' choice of actions but does not consider plaintiffs' choice of which managerial actions to challenge. It seems reasonable to assume that the plaintiff estimates the correct (efficient) legal standard with the same amount of error as the defendant. Accordingly, as to any managerial act, there are four different possible combinations of wrongfulness and suit, represented by Figure 1 .

\begin{tabular}{|l|l|l|}
\hline & \multicolumn{2}{|c|}{ Manager's (defendant's) action } \\
\hline $\begin{array}{l}\text { Shareholder's } \\
\text { (plaintiff's) } \\
\text { reaction }\end{array}$ & optimal, sue & nonoptimal, sue \\
\cline { 2 - 3 } & optimal, don't sue & $\begin{array}{l}\text { nonoptimal, don't } \\
\text { sue }\end{array}$ \\
\hline
\end{tabular}

Figure 1. Combinations of managerial and shareholder actions given indeterminate legal standards

Shareholders, in other words, will make both type I and type II error. Sometimes they will sue even though the manager's behavior turns out to be optimal, and sometimes they will fail to sue even though the manager's behavior was wrongful (nonoptimal). Given the assumed similarity of their estimates and those of the managers, the two types of error should be equally likely.

Kamar focuses on minimizing type II error. When the court can be counted on to provide the correct answer on average, maximizing suits will minimize type II error. More suits will provide more guidance and, ultimately, more efficient managerial decisions. When we allow for type I error, however, the picture becomes more complicated. If we assume that the court will provide the correct answer on average, managers will receive appropriate signals to guide their future conduct. Firms will also pay, and shareholders receive, optimal damage awards on average. However, firms and shareholders will incur excessive litigation 
costs. Litigation is expensive even to those parties who are found to have met their legal duties.

In order for shareholders to know whether and to what extent they should subsidize litigation, they need to know the relative costs of type I and type II error. Will the litigation costs created by director and officer liability insurance exceed the value of the legal precedents that are not created in the absence of litigation? To answer the question, we need a full-scale analysis of the social costs and benefits of litigation. We can, however, say something interesting about the likely effects of the marginal lawsuit, to which I will now turn.

\section{B. New Versus Repeat Issues}

In order to view litigation as an important source of guidance for managers, we should consider the extent to which the signals it generates are useful and reliable. As a thought experiment, imagine that the set of possible actions in some setting can be represented by a single variable, $x$, and the optimal action is $x^{*}$. Managers, by hypothesis, do not know the precise location of $x^{*}$. In Kamar's analysis, consideration of legal precedent enables managers to make more accurate guesses about that location. Following Kamar, let us think of the legal standard as having some distribution centered on $x^{*}$. By that I mean that each relevant prior judicial decision is a realization of a random variable that I will assume is normally distributed with mean $x^{*}$. Parties observe the prior judicial decisions, calculate the mean of the realizations, $\bar{x}$, and take it as a statistic for $x^{*}$.

Given random sampling (itself a questionable assumption), ${ }^{8}$ $\bar{x}$ will be an unbiased estimate of $x^{*}$. The precision of the estimate increases as the number of prior decisions, $n$, increases, but at a diminishing rate. Formally, the standard error of the estimate is decreasing in the square root of $n$. Thus, by doubling the number of cases that raise a similar issue, we improve the precision of the parties' estimate of $x^{*}$ by a factor of roughly 1.4 .

The point may seem abstract, but it has some direct relevance to the present discussion. There are presumably only mod-

\footnotetext{
- Whether litigated disputes are distributed randomly over $x$ depends entirely on one's model of the selection of disputes for litigation. In the Priest/Klein model, one might argue that the "sampling" should be approximately random (that is, disputes near the center of the distribution have a higher probability of being selected than those at the tails). See George L. Priest and Benjamin Klein, The Selection of Disputes for Litigation, $13 \mathrm{~J}$ Legal Stud 1 (1984). Shareholder suits might be different because of the substantial shareholder/lawyer agency problem, which might produce a sample drawn more heavily from the tails of the distribution.
} 
est economies of scale in litigation, so the costs of bringing and defending the 75th case to raise the issue of fair dealing in an interested-party merger are roughly the same as the costs of any of the prior 74. However, the social benefit of the precedent generated by the 75th is dramatically less than the benefit of the first or second. This analysis assumes that the optimal behavior, $x^{*}$, remains constant over time. Considered over a period of decades, that assumption will often be incorrect, but it seems plausible over the short run. We would have to assume that the optimal behavior changes rapidly in order to believe that relitigating previously settled issues is as socially valuable as litigating "new" issues.

A subsidy program for litigation, then, should seek to subsidize litigation on new issues but not on repeat issues. Casual observation suggests that the bulk of shareholder litigation treads fairly well-worn paths for which the social benefits of new precedent are low. Moreover, although courts may award greater attorneys' fees for "novel" cases, casual observation again suggests that the most profitable strategy is to bring cookie-cutter cases and settle as quickly as possible. This is selfish behavior on the part of the lawyers who are being subsidized to create valuable precedents for the benefit of managers and shareholders. It suggests that insurance is either not a system of litigation subsidy or a terribly inefficient one that gives lawyers only weak incentives to file the "right" suits.

Indeed, to find a plausible system of litigation subsidy for the purpose of creating precedent, we should probably look somewhere other than corporate law. Products liability seems a more natural field to look for a litigation subsidy (provided by consumers). The amount of legal uncertainty seems greater than that in corporate law, as evidenced by the frequency with which novel claims are taken seriously. Consider the recent tobacco and gun industry lawsuits, for example. ${ }^{9}$ The presence of liability insurance is even more puzzling than in the corporate context because firms should be less risk-averse than individual managers. It is also a contractual setting in which opportunities for incidenceshifting are rife. The same consumers who bear the risk of injury may bear the expected costs of liability in higher product prices. ${ }^{10}$

- See David E. Rosenbaum, Echoes of Tobacco Battle in Gun Suits, NY Times A4 (Mar 21, 1999).

${ }^{10}$ There is of course scholarly debate about the extent to which the costs of liability fall on consumers or shareholders. For a combination of theoretical analysis and some empirical evidence, see Steven Garber, Product Liability and the Economics of Pharmaceuticals and Medical Devices 105-22 (RAND 1993). 
If litigation is sufficiently valuable that parties will subsidize it voluntarily, products liability is a natural place to expect the subsidy.

\section{CORPORATE LAW DOCTRINE AND THE PRODUCTION OF PRECEDENTS}

Having expressed my skepticism, I should also admit that I find Kamar's analysis intriguing. It turns what most of us think are vices into virtues, which has some appeal for those who like to find hidden sense underneath apparently dysfunctional legal doctrines.

To begin, consider the role of the class action lawyer. In most corporate law scholarship, the class attorney is the villainsomeone who decides to sue based solely on a personal costbenefit calculation unrelated to whether the suit would benefit shareholders. ${ }^{11}$ Proposals for reform focus on giving shareholders additional incentives to monitor this unfaithful agent. ${ }^{12}$

In Kamar's world, the unmonitored, unaccountable class action lawyer keeps the whole corporate law machine working smoothly. Precisely because he ignores what is in the shareholders' immediate best interests, he can help generate valuable precedents that benefit all investors and managers. Recognizing this, shareholders agree to a system in which they occasionally take money from one pocket and transfer it to the other, less the lawyers' fees.

Another issue on which Kamar's analysis gives us a very different take is whether fiduciary duties should be waivable. To most law and economics scholar's, the instinctive response is, "of course." Like many legal rules, fiduciary duties look like a good default rule that most parties would choose most of the time. When particular parties have other ways of solving agency problems, however, they should be allowed to do so. Yet judges are reluctant to permit contracting around fiduciary duties.

The judges have it right if an important function of litigation is to produce a public good. Rational shareholders, of course, will want to free ride on that public good without paying their share of the cost. They could do so by opting out of the subsidy system. Waiving managers' fiduciary duties seems an easy way to opt out.

\footnotetext{
"See John C. Coffee, Jr., Understanding the Plaintiffs Attorney: The Implications of Economic Theory for Private Enforcement of Law Through Class and Derivative Actions, 86 Colum L Rev 669, 677-84 (1986).

${ }^{12}$ See, for example, Elliott J. Weiss and John S. Beckerman, Let the Money Do the Monitoring: How Institutional Investors Can Reduce Agency Costs in Securities Class Actions, 104 Yale L J 2053 (1995).
} 
Some firms might conclude that the cost of additional managerial misbehavior without fiduciary duties would be less than the cost of the litigation subsidy. If many firms reasoned this way, they would all opt out and the subsidy program would collapse. Courts can keep this from happening by making fiduciary duties nonwaivable.

But this again leads me to think that Kamar's analysis actually fits corporate law less well than it might fit other areas. Consider, for example, the duty of care, which Kamar seems to view as the classic example of an indeterminate rule that needs lots of fleshing out. The duty of care is waivable in more respects than the somewhat more determinate duty of loyalty. After Smith $v$ Van Gorkom, ${ }^{13}$ the Delaware legislature decided to permit corporations to limit directors' liability for breaches of the duty of care. ${ }^{14}$ Following Kamar's analysis, we might say that Van Gorkom demonstrated that the duty of care was even more indeterminate than most lawyers had previously thought. If Kamar is correct, a sensible system of corporate law would have responded by increasing directors' liabilities for duty of care violations in order to increase the amount of litigation and clarify the scope of the duty. Instead, the Delaware legislature responded by allowing shareholders to reduce the liability, or in other words to decline to use their money to subsidize the further development of the law in this area.

If the litigation subsidy is a good idea, then allowing companies to limit liability is counterproductive. For those, like me, who suspect that litigation is an option best left for extreme situations, the provision makes a lot of sense-no one is required to opt out, but companies can if they wish.

I return, therefore, to the idea that the analysis might be more relevant to products liability than corporate law. The drawback of corporate law is that managers and shareholders are not merely in a market relationship (like manufacturer and consumer), but in a long-term relational contract that provides the parties ample opportunities to resolve their differences outside litigation. Products liability suits tend to arise in the context of one-shot transactions in which the costs of negotiating a detailed

${ }^{13} 488$ A2d 858 (Del 1985).

"4 8 Del Code Ann $\$ 102(\mathrm{~b})(7)$ (1998). 
set of standards of conduct are likely greater than the benefits. The creation of precedents seems more valuable in that setting. ${ }^{15}$

\section{CONCLUSION}

Shareholder Litigation Under Indeterminate Corporate Law ${ }^{16}$ is an interesting and well-executed idea with a somewhat dubious premise. The idea that the social benefits of litigation are so large as to merit a subsidy, despite litigation's all-too-obvious costs, is one that I would embrace only upon very strong evidence. At a minimum, I would want to see empirical verification that more litigation produces more shareholder wealth.

${ }^{15}$ Lest I be seen as advocating more products liability litigation, let me point out that this is a comparative point, not an absolute one. The right amount of products liability litigation is likely greater than the right amount of shareholder litigation. Whether both quantities are currently too large, too small, or just right is a separate matter outside the scope of the present discussion.

${ }^{16}$ Kamar, 66 U Chi L Rev 887 (cited in note 1). 


\section{SYMPOSIUM: FORMALISM REVISITED}

CLOSING REMARKS

A Brief Anatomy of
Adjudicative Rule-Formalism .............. Frank I. Michelman 934 